\title{
UPOSAŻENIE PROFESORA ZWYCZAJNEGO POLSKIEJ PAŃSTWOWEJ SZKOŁY AKADEMICKIEJ W OKRESIE OD 1 X 1923 DO 31 I 1934 R.
}

Zagadnienie wynagradzania za prace pracowników państwowych szkół wyższych II RP podejmowane jest w historiografii rzadko, choć ostatnio zaczyna to ulegać zmianie. Warto $\mathrm{w}$ tym miejscu wspomnieć niedawno opublikowaną pracę Małgorzaty Przeniosło, która odnosi się do tego interesującego i ważnego problemu, choć nieco ogólnie i w sposób uproszczony ${ }^{1}$. Tymczasem kwestie uposażeniowe pracowników państwowych w II RP należą do niezwykle złożonych i dotyczy to nie tylko szkolnictwa akademickiego.

W okresie międzywojennym obowiązywały cztery systemy ustalania wysokości uposażenia profesorów państwowych szkół wyższych. W pierwszym okresie, od 1 I 1919² do 30 VI 1920 r., obowiąywał ułomny system kwotowy. Ułomny, ponieważ nie był on systemem w pełnym tego słowa znaczeniu. Nie było bowiem jednego i spójnego aktu normatywnego, który określałby wszystkie podstawowe zasady wynagrodzeń. Poszczególne składniki wynagrodzeń i ich wysokość były określane doraźnie, do czasu pojawienia się nowej, również tymczasowej regulacji³

\footnotetext{
${ }^{1}$ M. Przeniosło, Dochody nauczycieli państwowych szkół akademickich w II Rzeczypospolitej (na przykładzie matematyków), RDSG, t. 68, 2008, s. 35-63.

${ }^{2}$ Wówczas objęto wynagrodzeniami profesorów uczelni galicyjskich. Na Uniwersytecie Warszawskim i Politechnice Warszawskiej profesorowie pojawili się dopiero w ciagu 1919 r., zastępując tzw. wykładających.

${ }^{3}$ Do ważniejszych aktów normatywnych w tym zakresie należały: Reskrypt Rady Regencyjnej z dnia 11 VI 1918 r. Tymczasowe przepisy służbowe dla urzędników państwowych, Dz. U. 1918, nr 6, poz. 13; Rozporządzenie Rady Ministrów z dnia 10 III 1919 r. w przedmiocie tymczasowej regulacji płac profesorów, docentów prywatnych i pomocniczych sił naukowych w szkołach wyższych na terytorium b. zaboru austriackiego, Dz. U. 1919, nr 42, poz. 302; Rozporządzenie Ministra Wyznań Religijnych i Oświecenia Publicznego z dnia 22 XI 1920 r. w sprawie poborów profesorów,
} 
W drugim okresie, trwającym od 1 VII 1920 do 30 IX 1923 r., obowiązywał system mnożnikowy. Miał on jednolita podstawę prawna, choć i ją trudno nazwać zupełna. Najogólniej mówiąc, obliczanie wysokości poszczególnych składników uposażenia w tym systemie opierało się na dwóch zmiennych: mnożnej i mnożniku, zależnych od różnych czynników określonych przepisami państwowymi (jak wielkość rodziny, miejsce pracy, staż pracy itd.), niektóre składowe uposażenia obliczane były jednak jeszcze inaczej. ${ }^{4}$. Wydaje się, że były trzy podstawowe powody rezygnacji z systemu mnożnikowego. Po pierwsze, był on bardzo skomplikowany, ustalanie wszystkich składowych uposażenia podstawowego musiało być horrorem nawet dla profesjonalistów, a spory w tym udział miała bałaganiarska działalność prawodawcy. Zmiany kosztów utrzymania, czyli po prostu inflacja, okazały się dla tego systemu zbyt trudnym sprawdzianem, zwłaszcza gdy ta przekształciła się w hiperinflację. Było po prostu zbyt wiele zmiennych, które należało wziąć pod uwagę.

Po drugie, wprowadzenie nowego systemu punktowego pozostawało $\mathrm{w}$ związku z planowana reformą walutowa przygotowywana przez Władysława Grabskiego, która miała w założeniach doprowadzić również do większej stabilności cen. System punktowy miał tę niewątpliwą zaletę, że zachowywał przejrzystość i spójność zarówno w warunkach inflacyjnych, jak i deflacyjnych. Przebudowa zasad wynagradzania funkcjonariuszy państwowych miała również pozytywnie wpłynąć na powodzenie zarówno przewalutowania z marki polskiej (mk) na złotego polskiego (zł), jak i zduszenie presji inflacyjnej, w sposób niepodkopujący zaufania pracowników budżetowych do państwa polskiego, mocno nadwyrężonego dotychczasową polityka płacowa państwa.

Po trzecie, sytuacja materialna funkcjonariuszy państwowych od końca lata 1923 r., a zwłaszcza jesienia, stała się katastrofalna, dalsze lekceważenie ich potrzeb groziło paraliżem struktur państwowych. Konieczność zmuszała do przebudowy systemu w sposób radykalny i przywracający zdolność uposażenia do zapewnienia utrzymania funkcjonariuszom i członkom ich rodzin.

docentów i pomocniczych sił naukowych w państwowych szkołach wyższych, „Monitor Polski” 1920, nr 46.

${ }^{4}$ Podstawą systemu była Ustawa z dnia 13 VII 1920 r. o uposażeniu profesorów, innych wykładających i pomocników naukowych w państwowych szkołach akademickich, Dz. U. 1920, nr 65, poz. 432, ogłoszona 31 VII 1920 r., weszła w życie z moca wsteczna 1 VII 1920 r. Nowelizowana raz: Ustawą z dnia 31 III 1922 r. o uposażeniu profesorów i pomocniczych sił naukowych w szkołach akademickich, Dz. U. 1922, nr 28, poz. 226, jednak skala tej nowelizacji była tak duża, że nowy akt prawny prawie zastapił stary. Uchylona 1 X 1923 r.: Ustawa z dnia 9 X 1923 r. o uposażeniu funkcjonariuszy państwowych i wojska, Dz. U. 1923, nr 116, poz. 924. 
Wprowadzenie systemu punktowego zapoczątkowało trzeci etap kształtowania płac profesorskich, trwajacy od 1 X 1923 do 31 I 1934 r. Obliczanie uposażenia opierało się na ustalonej stałej mnożnej, której wartość wyrażana była w ilości tzw. punktów uposażeniowych. Ich liczba dla każdego składnika uposażenia zależna była od różnych czynników określonych przepisami państwowymi, a wartość była zmienna w czasie i zależna od tempa inflacji. Podstawą tego systemu była Ustawa z dnia 9 X 1923 r. o uposażeniu funkcjonariuszy państwowych i wojska ${ }^{5}$.

W czwartym i zarazem ostatnim okresie, trwającym od 1 II 1934 r. do końca II RP, obowiazywał ponownie system kwotowy, tym razem pełny. Poszczególne składniki uposażenia ustalano bezpośrednio w zł, bez konieczności dokonywania jakichkolwiek przeliczeńn ${ }^{6}$.

\section{System punktowy}

Uposażenie profesorów zwyczajnych miało w systemie punktowym wspólną podstawę prawną z innymi funkcjonariuszami państwowymi, zarówno cywilnymi, jak i wojskowymi. Odróżniało to ten system od poprzedniego, który dla pracowników szkolnictwa akademickiego miał całkowicie odrębną regulację. System punktowy, spośród wszystkich wyżej wymienionych, obowiązywał zdecydowanie najdłużej, bo aż 10 lat i 4 miesiące. Był też logicznie pomyślany i całkiem dobrze sprawdzał się w warunkach długotrwałej inflacji.

Jednak w sytuacji dużej stabilności pieniądza, która zaistniała w latach trzydziestych, skomplikowanie systemu punktowego było nadmierne. W tym, jak się wydaje, należy doszukiwać się podstawowej przy-

${ }^{5}$ Dz. U. 1923, nr 116, poz. 924, ogłoszona 15 XI 1923 r., weszła w życie z moca wsteczna 1 X 1923 r. Sprostowana raz: Zarządzeniem Prezydenta Rzeczypospolitej z dnia 14 I 1924 r. w przedmiocie sprostowania błędu w ustawie z dnia 9 X $1923 \mathrm{r}$. o uposażeniu funkcjonariuszy państwowych i wojska, Dz. U. 1924, nr 3, poz. 15. Nowelizowana 17 razy, w tym $12 \mathrm{w}$ zakresie dot. szkolnictwa akademickiego. Wydano do niej 78 aktów wykonawczych, w tym $47 \mathrm{w}$ zakresie dot. szkolnictwa akademickiego. Uchylona 1 II 1934 r.: Rozporządzeniem Prezydenta Rzeczypospolitej z dnia 28 X 1933 r. o uposażeniu funkcjonariuszy państwowych, Dz. U. 1933, nr 86, poz. 663.

${ }^{6}$ Podstawa systemu było Rozporządzenie Prezydenta Rzeczypospolitej z dnia 28 X 1933 r. o uposażeniu funkcjonariuszy państwowych, Dz. U. 1933, nr 86, poz. 663, ogłoszone 30 X 1933 r., weszło w życie 1 II 1934 r., nowelizowane 7 razy, wydano do niego 21 aktów wykonawczych. Uchylone 1 I 1949 r.: Ustawą z dnia 4 II 1949 r. o uposażeniu pracowników państwowych i samorządowych oraz przewodniczących organów wykonawczych gmin wiejskich i miejskich, Dz. U. 1949, nr 7, poz. 39. 
czyny rezygnacji z niego w początkach $1934 \mathrm{r}$. i zastapienia go prostym systemem kwotowym.

\section{Klasyfikacja uposażeń}

Zasadniczo uposażenie profesora zwyczajnego dzieliło się na dwie części: podstawowe i uzupełniające. Uposażenie podstawowe przysługiwało każdemu profesorowi zwyczajnemu w całym okresie obowiazywania systemu punktowego. Uposażenie uzupełniające zaś tylko tym, którzy spełniali określone prawem kryteria (np. posiadali rodzinę lub pełnili dodatkowe funkcje) lub przysługiwało jedynie czasowo. Uposażenie podstawowe profesora zwyczajnego tworzyły trzy składniki: płaca zasadnicza, dodatek regulacyjny oraz naukowy. Uposażenie uzupełniające profesora zwyczajnego mogły tworzyć maksymalnie cztery składniki: dodatek ekonomiczny, dodatek osobisty, dodatek funkcyjny, dodatek mieszkaniowy. Ustawodawstwo dopuszczało możliwość ustanawiania przez Radę Ministrów jeszcze innych dodatków, uzasadnionych szczególnymi właściwościami służby lub pełnieniem służby w stolicy. Jednak brak jest przesłanek, że w odniesieniu do profesorów zwyczajnych z takiej możliwości skorzystano.

W niniejszej pracy interesuje nas jedynie wynagrodzenie ściśle związane z pełnieniem funkcji profesora zwyczajnego, dlatego pomijamy $\mathrm{w}$ niej uposażenia dodatkowe, jak przykładowo $\mathrm{z}$ tytułu zastępstw lub prowadzenia zajęć zleconych.

Profesor zwyczajny mógł otrzymywać od Skarbu Państwa tylko jedno stałe uposażenie służbowe, jako wynagrodzenie za ogół czynności, których obowiązek wykonywania wynikał z zajmowania tego stanowiska. Jeżeli profesor otrzymał mieszkanie w naturze, jego wartość potrącano z uposażenia podstawowego.

Uposażenie wypłacane było miesięcznie, z góry, w 1. dniu każdego miesiąca kalendarzowego, a jeżeli dzień ten był ustawowo wolny od pracy (niedziela lub święto), w ostatnim dniu poprzedniego miesiacca.

Profesorowi zwyczajnemu, w przypadku zasługującym na uwzględnienie, mogła być udzielona bezprocentowa zaliczka na uposażenie. Warunki przyznawania takiej zaliczki i jej wysokość określał Prezes Rady Ministrów, w porozumieniu z ministrem skarbu ${ }^{7}$.

\footnotetext{
${ }^{7}$ Dz. U. 1923, nr 116, poz. 924.
} 


\section{Wartość punktu uposażeniowego (mnożna)}

Podstawowym pojęciem interesującego nas systemu wynagrodzeń był punkt uposażeniowy, który dalej będzie zwany punktem. Zdecydowana większość składników uposażenia profesorskiego, ale również innych wynagrodzeń (za czynności zlecone, zastępstwa itd.), była określana pewną liczba punktów. Liczba ta była w założeniach niezmienna, $\mathrm{w}$ praktyce zdarzały się jednak nieliczne modyfikacje w tym zakresie. Zmienna była natomiast wartość punktu, wyrażana początkowo $\mathrm{w} \mathrm{mk}$, a od 1 V 1924 r. w zł. Wartość punktu zwano mnożna, gdyż obliczenie rzeczywistej wartości wynagrodzeń polegało na pomnożeniu liczby punktów przypisanych danemu składnikowi uposażenia przez bieżąca wartość punktu.

Taka konstrukcja systemu wynagrodzeń pozwalała na dość elastyczne reagowanie na zmiany cen konsumpcyjnych w gospodarce, a co za tym idzie pozwalała na lepszą ochronę siły nabywczej uposażenia. W praktyce jednak o skuteczności tej ochrony decydowała wola i możliwości władz państwowych. Co do pierwszego czynnika, to przynajmniej w pierwszych latach obowiazywania systemu punktowego państwo starało się odzyskać nadszarpnięte latem $1923 \mathrm{r}$. zaufanie pracowników tzw. sfery budżetowej. Do czasu zdławienia inflacji rząd starał się, aby zmiany wysokości mnożnej w miarę dokładnie odzwierciedlały spadająca wartość nabywczą waluty polskiej.

Pierwotna mnożna została ustalona na kwotę $11600 \mathrm{mk}^{8}$. Zmiany mnożnej dokonywała Rada Ministrów, na wniosek ministra spraw wewnętrznych, zgłaszany $\mathrm{w}$ porozumieniu z ministrem skarbu. Mnożna taka mogła być określona zarówno w mk, jak i w zł, która to możliwość została wprowadzona $\mathrm{w}$ związku $\mathrm{z}$ projektowana reforma walutowa i związana $z$ nia zmiana jednostki pieniężnej.

Określenie wysokości mnożnej musiało następować najpóźniej 20. dnia każdego miesiąca na następny miesiąc, w oparciu o zmianę kosztów utrzymania w okresie od 15 . dnia poprzedniego miesiaca do 15. dnia bieżacego miesiąca i ewentualna zamianę $\mathrm{w}$ wysokości dodatku regulacyjnego. W razie wzrostu kosztów utrzymania w 2. połowie miesiąca, przekraczającego 15\%, Rada Ministrów, na wniosek ministra spraw wewnętrznych, zgłoszony w porozumieniu $\mathrm{z}$ ministrem skarbu, zarządzała wypłatę 16 . dnia tytułem dopłaty na pobory tego miesiąca kwotę, o którą należało by zwiększyć uposażenie,

${ }^{8}$ Kwota ta miała odpowiadać kosztom utrzymania w pierwszej połowie września $1923 \mathrm{r}$ 
biorąc pod uwagę wzrost kosztów utrzymania w 2. połowie ubiegłego miesiąca ${ }^{9}$.

Zmiana wartości punktu miała zatem następować zasadniczo raz, a najwyżej dwa razy w miesiącu. System taki obowiązywał wyłącznie do 31 XII 1925 r. Wówczas, wobec osiagnięcia stabilizacji cenowej, zrezygnowano z comiesięcznej modyfikacji, przyjmujacc odtąd już stała mnożną o wartości z 1 XII 1925 r. Jednak w razie ponownego powrotu inflacji można było powrócić do pierwotnych rozwiązań.

Wspomniane zaś dopłaty w połowie miesiąca okazały się konieczne tylko w I kwartale obowiązywania systemu punktowego, czyli od $1 \mathrm{X}$ do 31 XII 1923 r. W związku ze wzrostem kosztów utrzymania we wrześniu 1923 r. Rada Ministrów zarządziła dopłatę do uposażenia w październiku. Wysokość tej dopłaty wynosiła $2100 \mathrm{mk}$. Tym samym rzeczywista wartość punktu w październiku wyniosła $13700 \mathrm{mk}$. Mnożna na listopad 1923 r. została wyznaczona w wysokości $25520 \mathrm{mk}$. Ale w związku ze wzrostem kosztów utrzymania w 2 . połowie października od razu zarządzono dopłatę do tej mnożnej w wysokości $17100 \mathrm{mk}$. Tym samym rzeczywista wartość punktu w listopadzie wyniosła $42620 \mathrm{mk}^{10}$. Mnożna na grudzień $1923 \mathrm{r}$. została wyznaczona w wysokości $64380 \mathrm{mk}^{11}$. Ale w związku ze wzrostem kosztów utrzymania w 2. połowie listopada zarządzono dopłatę do mnożnej w wysokości $34765 \mathrm{mk}^{12}$. Tym samym rzeczywista wartość punktu w grudniu wyniosła $99145 \mathrm{mk}$. Od początku $1924 \mathrm{r}$. szybkość inflacji nieco osłabła, dzięki czemu nie było już konieczne weryfikowanie wartości punktu w ciagu miesiąca. Zmiany ostatecznej wartości mnożnej od 1 X 1923 do 30 VI 1924 r. przedstawia tabela 1 . Obejmuje ona cały okres wypłat w mk.

Od 1 X 1923 do 1 IV 1924 r. płace obliczano i wypłat dokonywano tylko w mk (okres markowy). W związku z reformą walutowa od $1 \mathrm{~V}$ do 30 VI 1924 r. wypłaty można było w całości lub części dokonywać zarówno w mk, jak i w zł (okres przejściowy). Od 2. połowy 1924 r. wartość mnożnej i wypłat ustalano już jedynie w zł (okres złotowy).

${ }^{9}$ Dz. U. 1923, nr 116, poz. 924.

${ }^{10}$ Zob. Rozporządzenie Rady Ministrów z dnia 15 XI 1923 r. w przedmiocie ustalenia na miesiace październik i listopad 1923 r. mnożnej, miarodajnej dla określenia uposażenia funkcjonariuszy państwowych i wojska, Dz. U. 1923, nr 117, poz. 937.

${ }^{11}$ Zob. Rozporządzenie Rady Ministrów z dnia 19 XI 1923 r. w przedmiocie ustalenia na miesiąc grudzień 1923 r. mnożnej dla określenia uposażenia funkcjonariuszy państwowych i wojska, Dz. U. 1923, nr 121, poz. 973.

12 Zob. Rozporządzenie Rady Ministrów z dnia 3 XII 1923 r. w przedmiocie ustalenia mnożnej dla określenia dopłaty na miesiąc grudzień 1923 r. do uposażenia funkcjonariuszy państwowych i wojska, Dz. U. 1923, nr 124, poz. 1002. 
Tabela 1. Wartość mnożnej (punktu uposażeniowego) w poszczególnych miesiącach, w okresie od 1 X 1923 do 30 VI 1924 r. w mk m $^{13}$

\begin{tabular}{l|r}
\hline Okres & Mnożna \\
\hline X 1923 & 13700 \\
XI 1923 & 42620 \\
XII 1923 & 99145 \\
I 1924 & 165109 \\
II 1924 & 509064 \\
III 1924 & 657609 \\
IV 1924 & 623200 \\
V-VI 1924 & 648000 \\
\hline
\end{tabular}

Mnożna na lipiec, sierpień i wrzesień 1924 r. została wyznaczona w wysokości $0,35 \mathrm{zł}^{14}$, na październik - 0,38 $\mathrm{zł}^{15}$, a na listopad i grudzień - 0,41 zł' $\mathrm{zł}^{16}$. W 1925 r. jej wartość wynosiła: w styczniu i lutym - 0,42 $\mathrm{zl}^{17}$, w marcu, kwietniu i maju - 0,41 $\mathrm{zł}^{18}$, w czerwcu -

${ }^{13}$ Oprac. własne na podstawie: Dz. U. 1923, nr 116, poz. 924; tamże, nr 117, poz. 937; tamże, nr 121, poz. 973; tamże, nr 124, poz. 1002; tamże, nr 131, poz. 1066; Dz. U. 1924, nr 7, poz. 68 ; tamże, nr 17, poz. 174 ; tamże, nr 28, poz. 277 ; tamże, nr 35 , poz. 370; tamże, nr 43, poz. 453.

${ }^{14}$ Rozporządzenie Rady Ministrów z dnia 16 VI 1924 r. w przedmiocie ustalenia na miesiąc lipiec $1924 \mathrm{r}$. mnożnej dla określenia uposażenia funkcjonariuszy państwowych i wojska, Dz. U. 1924, nr 52, poz. 527; Rozporządzenie Rady Ministrów z dnia 18 VII 1924 r. w przedmiocie ustalenia na miesiąc sierpień 1924 r. mnożnej dla określenia uposażenia funkcjonariuszy państwowych i wojska, tamże, nr 64, poz. 632; Rozporządzenie Rady Ministrów z dnia 19 VIII 1924 r. w przedmiocie ustalenia na miesiąc wrzesień 1924 r. mnożnej dla określenia uposażenia funkcjonariuszy państwowych i wojska, tamże, nr 73, poz. 726 .

${ }^{15}$ Rozporządzenie Rady Ministrów z dnia 17 IX 1924 r. w przedmiocie ustalenia na miesiąc październik 1924 r. mnożnej dla określenia uposażenia funkcjonariuszy państwowych i wojska, Dz. U. 1924, nr 82, poz. 784.

${ }^{16}$ Rozporządzenie Rady Ministrów z dnia 20 X 1924 r. o ustaleniu na miesiąc listopad 1924 r. mnożnej dla określenia uposażenia funkcjonariuszy państwowych i wojska, Dz. U. 1924, nr 93, poz. 867; Rozporządzenie Rady Ministrów z dnia 19 XI 1924 r. o ustaleniu na miesiąc grudzień 1924 r. mnożnej dla określenia uposażenia funkcjonariuszy państwowych i wojska, tamże, nr 101, poz. 929.

${ }^{17}$ Rozporządzenie Rady Ministrów z dnia 17 XII 1924 r. w sprawie ustalenia na miesiąc styczeń 1925 r. mnożnej dla określenia uposażenia funkcjonariuszy państwowych i wojska, Dz. U. 1924, nr 112, poz. 997; Rozporządzenie Rady Ministrów z dnia 19 I 1925 r. w sprawie ustalenia na miesiąc luty 1925 r. mnożnej dla określenia uposażenia funkcjonariuszy państwowych i wojska, Dz. U. 1925, nr 7, poz. 52.

${ }^{18}$ Rozporządzenie Rady Ministrów z dnia 18 II 1925 r. o ustaleniu na miesiąc marzec 1925 r. mnożnej dla określenia uposażenia funkcjonariuszy państwowych i wojska, Dz. U. 1925, nr 18, poz. 132; Rozporządzenie Rady Ministrów z dnia 18 III 1925 r. 
0,40 $\mathrm{zł}^{19}$, w lipcu - 0,42 $\mathrm{zł}^{20}$, w sierpniu - 0,43 $\mathrm{zł}^{21}$, we wrześniu $0,42 \mathrm{zt}^{22}$, w październiku - 0,43 $\mathrm{zt}^{23}$, w listopadzie $-0,44 \mathrm{zt}^{24}$, w grudniu $-0,43 \mathrm{zt}^{25}$.

Od 1 I 1926 r. wynagrodzenia zostały zamrożone na poziomie z grudnia $1925 \mathrm{r}$. Z tym że przejściowo w I kwartale $1926 \mathrm{r}$. uposażenia zostały obniżone o 6\%. Od 1 IV 1926 r. osiagnęły założony poziom, przy stałej wartości mnożnej na poziomie 0,43 zł, która odtąd nie ulegała już żadnym zmianom do końca funkcjonowania systemu punktowego.

\section{Placa zasadnicza}

Wysokość płacy zasadniczej (zwanej również uposażeniem zasadniczym) wyrażano w liczbie punktów. Każda grupa uposażenia dzieliła się na kilka szczebli. W IV grupie, do której należał profesor zwyczajny, było pięć szczebli. Przy czym wyjątkowo - tylko dla profesorów zwyczajnych i nadzwyczajnych - utworzono dodatkowy, szósty szczebel. Każdy szczebel oznaczany był mała litera, przy czym najniższy był szczebel a, wyższe szły w kolejności alfabetycznej do najwyższego szczebla f.

o ustaleniu na miesiąc kwiecień 1925 r. mnożnej dla określenia uposażenia funkcjonariuszy państwowych i wojska, tamże, nr 28, poz. 198; Rozporządzenie Rady Ministrów z dnia 18 IV 1925 r. o ustaleniu na miesiąc maj 1925 r. mnożnej dla określenia uposażenia funkcjonariuszy państwowych i wojska, tamże, nr 41, poz. 281.

${ }^{19}$ Rozporządzenie Rady Ministrów z dnia 20 V 1925 r. o ustaleniu na miesiąc czerwiec 1925 r. mnożnej dla określenia uposażenia funkcjonariuszy państwowych i wojska, Dz. U. 1925, nr 54, poz. 391.

${ }^{20}$ Rozporządzenie Rady Ministrów z dnia 17 VI 1925 r. o ustaleniu na miesiąc lipiec 1925 r. mnożnej dla określenia uposażenia funkcjonariuszy państwowych i wojska, Dz. U. 1925, nr 62, poz. 437.

${ }^{21}$ Rozporządzenie Rady Ministrów z dnia 18 VII 1925 r. o ustaleniu na miesiąc sierpień 1925 r. mnożnej dla określenia uposażenia funkcjonariuszy państwowych i wojska, Dz. U. 1925, nr 74, poz. 517.

${ }^{22}$ Rozporządzenie Rady Ministrów z dnia 18 VIII 1925 r. o ustaleniu na miesiąc wrzesień 1925 r. mnożnej dla określenia uposażenia funkcjonariuszy państwowych i wojska, Dz. U. 1925, nr 86, poz. 593.

${ }^{23}$ Rozporządzenie Rady Ministrów z dnia 19 IX 1925 r. o ustaleniu na miesiąc październik 1925 r. mnożnej dla określenia uposażenia funkcjonariuszy państwowych i wojska, Dz. U. 1925, nr 97, poz. 685.

${ }^{24}$ Rozporządzenie Rady Ministrów z dnia 19 X 1925 r. o ustaleniu na miesiąc listopad 1925 r. mnożnej dla określenia uposażenia funkcjonariuszy państwowych i wojska, Dz. U. 1925, nr 107, poz. 762.

${ }^{25}$ Rozporządzenie Rady Ministrów z dnia 17 XI 1925 r. o ustaleniu na miesiąc grudzień 1925 r. mnożnej dla określenia uposażenia funkcjonariuszy państwowych i wojska, Dz. U. 1925, nr 117, poz. 839. 
Do każdego z nich przypisana była zasadniczo stała liczba punktów ${ }^{26}$. W całym okresie obowiazywania systemu punktowego tylko raz dokonano zmiany w tym zakresie - 1 I 1926 r. obniżono dla szczebla f liczbę punktów z 1900 do $1850^{27}$. Pierwotną liczbę punktów przypisaną do każdego szczebla uposażenia dla profesorów zwyczajnych przedstawia tabela 2 .

Tabela 2. Punkty uposażeniowe przysługujące poszczególnym szczeblom uposażeniowym przypisanym stanowisku profesora zwyczajnego ${ }^{28}$

\begin{tabular}{c|c}
\hline Szczebel uposażenia & Liczba punktów \\
\hline a & 1400 \\
b & 1500 \\
c & 1600 \\
d & 1700 \\
e & 1800 \\
f & 1900 \\
\hline
\end{tabular}

Profesorowi zwyczajnemu przyznawano szczebel służbowy odpowiadający dotychczasowemu okresowi wysługi lat (w systemie mnożnikowym). Przy czym czas polskiej służby państwowej na stanowisku profesora zwyczajnego bezpośrednio sprzed 1 X 1923 r. zaliczano w całości, czas zaś poprzedni w proporcji 6 miesięcy za każde pełne trzylecie. Okresu poniżej 3 lat nie uwzględniano.

Przy pierwszym mianowaniu profesor zwyczajny zasadniczo otrzymywał uposażenie pierwszego szczebla dla IV grupy uposażenia. Jeżeli jednak profesor zwyczajny przed mianowaniem był już funkcjonariuszem państwowym V grupy uposażenia (np. profesorem nadzwyczajnym), otrzymywał uposażenie tego szczebla, który pod względem liczby punktów był bezpośrednio wyższy od szczebla zajmowanego poprzednio w niższej grupie uposażenia. Jeżeli jednak następny szczebel w V grupie uposażenia był wyższy (od 1 III 1928 r. także gdyby był

${ }^{26}$ Dz. U. 1923, nr 116, poz. 924.

${ }^{27}$ Ustawa z dnia 22 XII 1925 r. o środkach zapewnienia równowagi budżetowej, Dz. U. 1925, nr 129, poz. 918.

${ }^{28}$ Szczebel f nie istniał w IV grupie uposażenia funkcjonariuszy państwowych, przesunięcie na ten szczebel przysługiwało wyłącznie profesorom zwyczajnym i nadzwyczajnym, na mocy szczególnego przywileju. Pierwotnie przyjmował on wielkość podaną w tabeli, od 1 I 1926 r. liczbę punktów tego szczebla zmniejszono do poziomu 1850. Oprac. własne na podstawie: Dz. U. 1923, nr 116, poz. 924; Dz. U. 1925, nr 129, poz. 918. 
równy ${ }^{29}$ ) pod względem liczby punktów niż szczebel osiagnięty w grupie IV, to czas spędzony na ostatnio zajmowanym szczeblu grupy niższej wliczano do trzyletniego okresu przesunięcia następnego w grupie wyższej. Powyższa sytuacja rzeczywiście występowała, profesor nadzwyczajny szczebla d miał bowiem identyczną liczbę punktów z profesorem zwyczajnym szczebla a.

Od 1 X 1923 do 29 VI 1931 r. przejście na wyższy poziom uposażenia odbywało się automatycznie co 3 lata, w stałych terminach półrocznych: 1 stycznia i 1 lipca każdego roku ${ }^{30}$.

Miesięczną płacę zasadniczą danego profesora zwyczajnego obliczano, mnożąc liczbę punktów przysługujących mu zgodnie z posiadanym szczeblem uposażenia przez każdorazową wartość punktu, czyli mnożna. Wysokość płacy zasadniczej w okresie markowym przedstawia tabela 3.

Tabela 3. Miesięczna płaca zasadnicza profesora zwyczajnego w okresie od 1 X 1923 do 30 VI 1924 r. w $\mathrm{mk}^{31}$

\begin{tabular}{|c|c|c|c|c|c|c|}
\hline \multirow{2}{*}{ Okres } & \multicolumn{6}{|c|}{ Szczeble uposażenia } \\
\hline & $\mathbf{a}$ & $\mathbf{b}$ & $\mathbf{c}$ & d & $\mathbf{e}$ & $\mathbf{f}$ \\
\hline X 1923 & 19180000 & 20550000 & 21920000 & 23290000 & 24660000 & 26030000 \\
\hline XI 1923 & 59668000 & 63930000 & 68192000 & 72454000 & 76716000 & 80978000 \\
\hline XII 1923 & 138803000 & 148717500 & 158632000 & 168546500 & 178461000 & 188375500 \\
\hline I 1924 & 231152600 & 247663500 & 264174400 & 280685300 & 297196200 & 313707100 \\
\hline II 1924 & 712689600 & 763596000 & 814502400 & 865408800 & 916315200 & 967221600 \\
\hline III 1924 & 920652600 & 986413500 & 1052174400 & 1117935300 & 1183696200 & 1249457100 \\
\hline IV 1924 & 872480000 & 934800000 & 997120000 & 1059440000 & 1121760000 & 1184080000 \\
\hline V-VI 1924 & 907200000 & 972800000 & 1036800000 & 1101600000 & 1166400000 & 1231200000 \\
\hline
\end{tabular}

Od 1 I do 31 III 1926 r. w związku z wejściem w życie Ustawy z 1925 r. o środkach zapewnienia równowagi budżetowej płaca za-

${ }^{29}$ Rozporządzenie Prezydenta Rzeczypospolitej z dnia 22 marca 1928 r. w sprawie zmiany niektórych przepisów o uposażeniu funkcjonariuszy państwowych i wojska oraz sędziów i prokuratorów, Dz. U. 1928, nr 38, poz. 370.

${ }^{30} \mathrm{Dz}$. U. 1923, nr 116, poz. 924, przepis zawieszony przez Ustawę z dnia $14 \mathrm{X}$ 1931 r. o zmianie niektórych postanowień ustawy o uposażeniu funkcjonariuszy państwowych i wojska oraz sędziów i prokuratorów, Dz. U. 1931, nr 98, poz. 749.

${ }^{31}$ Oprac. i obliczenia własne na podstawie: Dz. U. 1923, nr 116, poz. 924; tamże, nr 117, poz. 937; tamże, nr 121, poz. 973; tamże, nr 124, poz. 1002; tamże, nr 131, poz. 1066; Dz. U. 1924, nr 7, poz. 68; tamże, nr 17, poz. 174; tamże, nr 28, poz. 277; tamże, nr 35, poz. 370; tamże, nr 43, poz. 453. 
sadnicza według stanu na 1 XII 1925 r. została zmniejszona o 6\%, od 1 kwietnia wróciła do poprzedniego poziomu ${ }^{32}$. Po tej regulacji wysokość płacy zasadniczej nie uległa zmianie do końca obowiązywania systemu punktowego.

Tabela 4 przedstawia wysokość rzeczywistej miesięcznej płacy zasadniczej od 1 V 1924 do 31 I 1934 r. w zł.

Tabela 4. Miesięczna płaca zasadnicza profesora zwyczajnego w okresie od 1 V 1924 do 31 I 1934 r. w zł ${ }^{33}$

\begin{tabular}{l|c|c|c|c|c|c}
\hline \multirow{2}{*}{\multicolumn{1}{c|}{ Okres }} & \multicolumn{5}{c}{ Szczeble uposażenia } \\
\cline { 2 - 7 } & a & b & c & d & e & f \\
\hline V-VI 1924 & 504,00 & 540,00 & 576,00 & 612,00 & 648,00 & 684,00 \\
VII-IX 1924 & 490,00 & 525,00 & 560,00 & 595,00 & 630,00 & 665,00 \\
X 1924 & 532,00 & 570,00 & 608,00 & 646,00 & 684,00 & 722,00 \\
XI-XII 1924 & 574,00 & 615,00 & 656,00 & 697,00 & 738,00 & 779,00 \\
I-II 1925 & 588,00 & 630,00 & 672,00 & 714,00 & 756,00 & 798,00 \\
III-V 1925 & 574,00 & 615,00 & 656,00 & 697,00 & 738,00 & 779,00 \\
VI 1925 & 560,00 & 600,00 & 640,00 & 680,00 & 720,00 & 760,00 \\
VII 1925 & 588,00 & 630,00 & 672,00 & 714,00 & 756,00 & 798,00 \\
VIII 1925 & 602,00 & 645,00 & 688,00 & 731,00 & 774,00 & 817,00 \\
IX 1925 & 588,00 & 630,00 & 672,00 & 714,00 & 756,00 & 798,00 \\
X 1925 & 602,00 & 645,00 & 688,00 & 731,00 & 774,00 & 817,00 \\
XI 1925 & 616,00 & 660,00 & 704,00 & 748,00 & 792,00 & 836,00 \\
XII 1925 & 602,00 & 645,00 & 688,00 & 731,00 & 774,00 & 817,00 \\
I-III 1926 & 565,88 & 606,30 & 646,72 & 687,14 & 727,56 & 747,77 \\
IV 1926-I 1934 & 602,00 & 645,00 & 688,00 & 731,00 & 774,00 & 795,50 \\
\hline
\end{tabular}

${ }^{32}$ Dz. U. 1925, nr 129, poz. 918.

${ }^{33}$ Oprac. i obliczenia własne na podstawie: Dz. U. 1923, nr 116, poz. 924; tamże, nr 117, poz. 937; tamże, nr 121, poz. 973; tamże, nr 124, poz. 1002; tamże, nr 131, poz. 1066 ; Dz. U. 1924 , nr 7, poz. 68 ; tamże, nr 17, poz. 174 ; tamże, nr 28 , poz. 277 ; tamże, nr 35, poz. 370; tamże, $\mathrm{nr} 43$, poz. 453; tamże, nr 52, poz. 527; tamże, nr 64, poz. 632 ; tamże, nr 73 , poz. 726 ; tamże, nr 82 , poz. 784 ; tamże, nr 93 , poz. 867 ; tamże, nr 101, poz. 929; tamże, nr 112, poz. 997; Dz. U. 1925, nr 7, poz. 52; tamże, nr 18, poz. 132; tamże, nr 28, poz. 198; tamże, nr 41, poz. 281; tamże, nr 54, poz. 391; tamże, nr 62, poz. 437; tamże, nr 74, poz. 517; tamże, nr 86, poz. 593; tamże, nr 97, poz. 685; tamże, nr 107, poz. 762; tamże, nr 117, poz. 839; tamże, nr 129, poz. 918. 


\section{Dodatek regulacyjny}

Od 1 X 1923 r. wprowadzono dodatek regulacyjny do płacy zasadniczej. Miał on obowiązywać przez okres przejściowy, tzw. sanacji Skarbu Państwa. Zmiany wartości punktu uposażeniowego miały co prawda zniwelować wysokość inflacji, ale były przeprowadzane zasadniczo raz lub dwa w miesiącu. Tymczasem hiperinflacja oznaczała gwałtowne podwyżki cen w bardzo krótkim czasie, często z dnia na dzień. Dodatek regulacyjny miał zatem stanowić pewną rezerwę na wypadek zbyt szybkiego wzrostu kosztów utrzymania. Pierwotną wartość dodatku regulacyjnego ustalono na 70 pkt. Wraz ze zmniejszaniem się tempa inflacji dodatek ten miał być stopniowo zmniejszany, a następnie zlikwidowany. Rada Ministrów, na wniosek ministra skarbu, w zależności od rezultatów owej sanacji została upoważniona do ustalenia terminu rozpoczęcia redukcji dodatku regulacyjnego ${ }^{34}$. Termin ten został ostatecznie wyznaczony na 1 VII 1925 r. i wówczas doszło do pierwszej jego redukcji ${ }^{35}$.

Redukcja dodatku regulacyjnego była przewidywana na okres 36 miesięcy. Jego wielkość, wyrażana w punktach, była równa dla wszystkich szczebli uposażenia Od dnia rozpoczęcia redukcji co pół roku miała ona ulegać zmniejszeniu o 10 pkt., z mocy prawa ${ }^{36}$. Wraz z ostatnia redukcja dodatek spadłby do 0 i tym samym nie byłby dalej wypłacany, przestając być częścią składową uposażenia podstawowe$\mathrm{go}^{37}$. Jednak w praktyce doszło jedynie do pierwszej redukcji dodat-

${ }^{34}$ Dz. U. 1923, nr 116, poz. 924.

${ }^{35}$ Rozporządzenie Rady Ministrów z dnia 17 VI 1925 r. w sprawie ustalenia terminu stopniowej redukcji dodatku regulacyjnego, Dz. U. 1925, nr 62, poz. 438.

${ }^{36}$ Odpowiednio 1 stycznia albo 1 lipca. W I półroczu redukcji spadał o 10 pkt., a jego wartość od 1. do 6. miesiąca redukcji wynosiła 60 pkt. W II półroczu redukcji spadał o dalsze 10 pkt., co oznaczało łącznie zmniejszenie jego pierwotnej wysokości o 20 pkt., a jego wartość od 7. do 12 . miesiąca redukcji wynosiła 50 pkt. W III półroczu redukcji spadał o dalsze 10 pkt., co oznaczało łacznie zmniejszenie jego pierwotnej wysokości o 30 pkt., a jego wartość od 13. do 18. miesiąca redukcji wynosiła 40 pkt. W IV półroczu redukcji spadał o dalsze 10 pkt., co oznaczało łącznie zmniejszenie jego pierwotnej wysokości o 40 pkt., a jego wartość od 19. do 24 . miesiąca redukcji wynosiła 30 pkt. W V półroczu redukcji spadał o dalsze 10 pkt., co oznaczało łacznie zmniejszenie jego pierwotnej wysokości o 50 pkt., a jego wartość od 25. do 30. miesiąca redukcji wynosiła 20 pkt. W VI półroczu redukcji spadał o dalsze 10 pkt., co oznaczało łacznie zmniejszenie jego pierwotnej wysokości o 60 pkt., a jego wartość od 31. do 36. miesiąca redukcji wynosiła $10 \mathrm{pkt}$. Z upływem VI półrocza redukcji dodatek regulacyjny zmniejszał się o ostatnie 10 pkt., spadając do 0 i tym samym przestając być częścią składową uposażenia podstawowego.

${ }^{37}$ Dz. U. 1923, nr 116, poz. 924. 
ku regulacyjnego, po czym pozostawiono go już na stałym poziomie -60 pkt.

Przez pierwsze 7 miesięcy od wejścia $\mathrm{w}$ życie systemu punktowego dodatek regulacyjny wypłacano wyłącznie w mk. Jego wysokość wzrosła z 959 tys. mk w październiku 1923 r. do 45360000 mk (25,20 zł) w maju-czerwcu $1924 \mathrm{r}^{38}$ Od 1 VII $1924 \mathrm{r}$. jego wypłaty dokonywano już wyłącznie w zł. 1 VII 1925 r. przeprowadzono redukcję dodatku regulacyjnego do poziomu 60 pkt. Od tego momentu pozostał na stałym poziomie. Przy mnożnej 0,43 zł, wynosił 25,80 zł miesięcznie.

\section{Dodatek naukowy}

W systemie punktowym utrzymano dodatek naukowy do uposażenia zasadniczego, znany w poprzednim systemie mnożnikowym. Konstrukcja dodatku naukowego była identyczna jak dodatku regulacyjnego. Oznaczało to, że ustawodawca nadał profesorom zwyczajnym i nadzwyczajnym szczególny przywilej, dodatkowo zabezpieczajacy ich przed gwałtownością procesów inflacyjnych. Zachodzi więc pytanie o przyczynę takiego wyróżnienia. Otóż wydaje się, że jedynym powodem była specyficzna struktura wydatków tej grupy społecznej. Profesorowie, zarówno jako uczeni, jak i nauczyciele akademiccy, dla skutecznego wykonywania swych obowiązków byli zmuszeni do dokonywania zakupu książek, materiałów piśmienniczych itp. A specyfika pracy naukowej wymusza wykonywanie wielu prac i przygotowań w warunkach domowych. Nawet najlepiej zaopatrzone biblioteki i laboratoria nie mogły całkowicie wyeliminować takiej konieczności. Aby zatem inflacja nie wpłynęła ujemnie na pracę profesorów, poprzez ograniczanie wydatków na pomoce naukowe, uznano za koniecznie ustanowienie dodatku naukowego. Wyliczany był on podobnie jak płaca zasadnicza, poprzez pomnożenie liczby punktów przypisanych temu typowi dodatku $\mathrm{w}$ danym miesiącu i mnożnej obowiązującej w okresie, za który dodatek naukowy był wypłacany ${ }^{39}$.

Pierwotną wartość dodatku naukowego ustalono na 350 pkt. Jego redukcja była przewidywana na okres 36 miesięcy. Od dnia rozpoczęcia redukcji co pół roku miał on ulegać zmniejszeniu z mocy prawa o 50 pkt. ${ }^{40}$ Wraz z ostatnią redukcją dodatek spadłby do 0 i tym sa-

${ }^{38}$ Dz. U. 1924, nr 35, poz. 370; tamże, nr 43, poz. 453.

${ }^{39}$ Dz. U. 1923, nr 116, poz. 924.

${ }^{40}$ Odpowiednio 1 stycznia albo 1 lipca. W I półroczu redukcji spadał o 50 pkt., a jego wartość od 1. do 6. miesiąca redukcji wynosiła 300 pkt. W II półroczu redukcji 
mym nie byłby dalej wypłacany, przestając być częścią składową uposażenia podstawowego ${ }^{41}$. Jednak doszło jedynie do pierwszej redukcji dodatku naukowego, po której nie ulegał on już dalszym zmianom. Miesięczną wartość dodatku naukowego w okresie markowym przedstawia tabela 5 .

Tabela 5. Miesięczny dodatek naukowy do płacy zasadniczej profesora zwyczajnego w okresie od 1 X 1923 do 30 VI 1924 r. w mk ${ }^{42}$

\begin{tabular}{l|c}
\hline Okres & Kwota \\
\hline X 1923 & 4795000 \\
XI 1923 & 14917000 \\
XII 1923 & 34700750 \\
I 1924 & 57788150 \\
II 1924 & 178172400 \\
III 1924 & 230163150 \\
IV 1924 & 218120000 \\
V-VI 1924 & 226800000 \\
\hline
\end{tabular}

W obu miesiącach przejściowych mnożna została ustalona na 648 tys. mk albo 0,36 zł. Zatem kwota dodatku naukowego wynosiła $226800000 \mathrm{mk}$ albo $126 \mathrm{zł}^{43}$. Od 1 VII 1924 r. jego wypłaty dokony-

spadał o dalsze 50 pkt., co oznaczało łącznie zmniejszenie jego pierwotnej wysokości o 100 pkt., a jego wartość od 7. do 12 . miesiąca redukcji wynosiła 250 pkt. W III półroczu redukcji spadał o dalsze 50 pkt., co oznaczało łącznie zmniejszenie jego pierwotnej wysokości o 150 pkt., a jego wartość od 13. do 18. miesiacca redukcji wynosiła 200 pkt. W IV półroczu redukcji spadał o dalsze 50 pkt., co oznaczało łącznie zmniejszenie jego pierwotnej wysokości o 200 pkt., a jego wartość od 19. do 24 . miesiąca redukcji wynosiła 150 pkt. W V półroczu redukcji spadał o dalsze 50 pkt., co oznaczało łącznie zmniejszenie jego pierwotnej wysokości o 250 pkt., a jego wartość od 25. do 30. miesiaca redukcji wynosiła 100 pkt. W VI półroczu redukcji spadał o dalsze 50 pkt., co oznaczało łącznie zmniejszenie jego pierwotnej wysokości o 300 pkt., a jego wartość od 31. do 36. miesiąca redukcji wynosiła 50 pkt. Z upływem VI półrocza redukcji dodatek naukowy zmniejszał się o ostatnie 50 pkt., spadając do 0 i tym samym przestając być częśsią składową uposażenia podstawowego.

${ }^{41}$ Dz. U. 1923, nr 116, poz. 924.

${ }^{42}$ Oprac. i obliczenia własne na podstawie: Dz. U. 1923, nr 116, poz. 924; tamże, nr 117, poz. 937; tamże, nr 121, poz. 973; tamże, nr 124, poz. 1002; tamże, nr 131, poz. 1066 ; Dz. U. 1924 , nr 7, poz. 68 ; tamże, nr 17, poz. 174 ; tamże, nr 28, poz. 277; tamże, nr 35, poz. 370; tamże, nr 43, poz. 453.

${ }^{43}$ Dz. U. 1924, nr 35, poz. 370; tamże, nr 43, poz. 453. 
wano już wyłącznie w zł. 1 VII 1925 r. rozpoczą się pierwszy etap redukcji dodatku naukowego. Pierwsza redukcja o 50 pkt. dotyczyła całego II półrocza 1925 r. i oznaczała spadek wielkości tego dodatku do poziomu $300 \mathrm{pkt}$.

Od 1 I 1926 r. zniesiono zasadę redukcji dodatku naukowego co pół roku, pozostawiajac go odtąd już na stałym poziomie. Jednak ów stały poziom został obniżony o 50\% stanu z 1 XII 1925 r., czyli z 300 do 150 pkt., przy stałej mnożnej wynoszącej $0,43 \mathrm{zł}$, co dawało stałą kwotę dodatku naukowego wynoszaca $64,50 \mathrm{zł}$ miesięcznie. Oznaczało to jednocześnie uznanie dodatku naukowego za stała składową uposażenia podstawowego. Tymczasowo w okresie od 1 I do 31 III 1926 r. kwota dodatku naukowego została zmniejszona o 6\% stanu stałego, co w intencji prawodawcy miało być jednym z czynników wspomagających osiągnięcie równowagi budżetowej przez Skarb Państwa. Oznaczało to, że w styczniu, lutym i marcu $1926 \mathrm{r}$. dodatek naukowy do płacy zasadniczej profesora zwyczajnego wynosił 60,63 zł, a od 1 kwietnia przyjmował wspomnianą stałą wysokość $64,50 \mathrm{zt}^{44}$.

\section{Uposażenie podstawowe - podsumowanie}

Po omówieniu poszczególnych składowych uposażenia podstawowego, można przedstawić proces kształtowania się zsumowanej jego wysokości w latach 1923-1934. Przypomnijmy, że miesięczne uposażenie podstawowe danego profesora zwyczajnego obliczamy poprzez dodanie kwot przysługujących mu w danym miesiącu: płacy zasadniczej, dodatku regulacyjnego i dodatku naukowego. Sposób obliczania uposażenia podstawowego można przedstawić w postaci wzoru. Wysokość miesięcznego uposażenia podstawowego profesora zwyczajnego od 1 X 1923 do 31 I 1934 r. wyraża wzór ${ }^{45}: \mathbf{U p}=\mathbf{P z}+\mathbf{D r}+\mathbf{D n}$, gdzie: Up to uposażenie podstawowe $\mathrm{w}$ danym miesiącu, $\mathrm{Pz}$ - płaca zasadnicza $\mathrm{w}$ danym miesiącu, Dr - dodatek regulacyjny w danym miesiącu, Dn - dodatek naukowy w danym miesiącu. Wysokość uposażenia podstawowego w okresie markowym przedstawia tabela 6 .

\footnotetext{
${ }^{44}$ Dz. U. 1925, nr 129, poz. 918.

${ }^{45}$ Oprac. własne na podstawie: Dz. U. 1923, nr 116, poz. 924.
} 
Tabela 6. Miesięczne uposażenie podstawowe profesora zwyczajnego w okresie od $1 \mathrm{X}$ 1923 do 30 VI 1924 r. w $\mathrm{mk}^{46}$

\begin{tabular}{l|r|r|r|r|r|r}
\hline \multirow{2}{*}{ Okres } & \multicolumn{7}{|c|}{ Szczeble uposażenia } \\
\cline { 2 - 8 } & \multicolumn{1}{|c|}{$\mathbf{a}$} & \multicolumn{1}{|c|}{ b } & \multicolumn{1}{c}{ c } & \multicolumn{1}{c}{ d } & \multicolumn{1}{c}{ e } & \multicolumn{1}{c}{$\mathbf{f}$} \\
\hline X 1923 & 24934000 & 26304000 & 27674000 & 29044000 & 30414000 & 31784000 \\
XI 1923 & 77568400 & 81830400 & 86092400 & 90354400 & 94616400 & 98878400 \\
XII 1923 & 180443900 & 190358400 & 200272900 & 210187400 & 220101900 & 230016400 \\
I 1924 & 300498380 & 317009280 & 333520180 & 350031080 & 366541980 & 383052880 \\
II 1924 & 926496480 & 977402880 & 1028309280 & 1079215680 & 1130122080 & 1181028480 \\
III 1924 & 1196848380 & 1262609280 & 1328370180 & 1394131080 & 1459891980 & 1525652880 \\
IV 1924 & 1134224000 & 1196544000 & 1258864000 & 1321184000 & 1383504000 & 1445824000 \\
V-VI 1924 & 1179360000 & 1244960000 & 1308960000 & 1373760000 & 1438560000 & 1503360000 \\
\hline
\end{tabular}

Tabela 7 przedstawia wysokość miesięcznego uposażenia podstawowego od 1 V 1924 do 31 I 1934 r. w zł.

Tabela 7. Miesięczne uposażenie podstawowe profesora zwyczajnego w okresie od 1 V 1924 do 31 I 1934 r. w zł ${ }^{47}$

\begin{tabular}{l|c|c|c|c|c|c}
\hline \multirow{2}{*}{\multicolumn{1}{c|}{ Okres }} & \multicolumn{7}{c}{ Szczeble uposażenia } \\
\cline { 2 - 7 } & a & b & c & d & e & f \\
\hline V-VI 1924 & 655,20 & 691,20 & 727,20 & 763,20 & 799,20 & 835,20 \\
VII-IX 1924 & 637,00 & 672,00 & 707,00 & 742,00 & 777,00 & 812,00 \\
X 1924 & 691,60 & 729,60 & 767,60 & 805,60 & 843,60 & 881,60 \\
XI-XII 1924 & 746,20 & 787,20 & 828,20 & 869,20 & 910,20 & 951,20 \\
I-II 1925 & 764,40 & 806,40 & 848,40 & 890,40 & 932,40 & 974,40
\end{tabular}

${ }^{46}$ Oprac. i obliczenia własne na podstawie: Dz. U. 1923, nr 116, poz. 924; tamże, nr 117, poz. 937; tamże, nr 121, poz. 973; tamże, nr 124, poz. 1002; tamże, nr 131, poz. 1066 ; Dz. U. 1924 , nr 7, poz. 68 ; tamże, nr 17 , poz. 174 ; tamże, nr 28 , poz. 277 ; tamże, nr 35, poz. 370; tamże, nr 43, poz. 453.

${ }^{47}$ Oprac. i obliczenia własne na podstawie: Dz. U. 1923, nr 116, poz. 924; tamże, nr 117, poz. 937; tamże, nr 121, poz. 973; tamże, nr 124, poz. 1002; tamże, nr 131, poz. 1066 ; Dz. U. 1924 , nr 7, poz. 68 ; tamże, nr 17, poz. 174 ; tamże, nr 28 , poz. 277 ; tamże, nr 35, poz. 370; tamże, nr 43, poz. 453; tamże, nr 52, poz. 527; tamże, nr 64, poz. 632 ; tamże, nr 73 , poz. 726 ; tamże, nr 82 , poz. 784 ; tamże, nr 93 , poz. 867 ; tamże, nr 101, poz. 929; tamże, nr 112, poz. 997; Dz. U. 1925 , nr 7 , poz. 52 ; tamże, nr 18 , poz. 132; tamże, nr 28, poz. 198; tamże, nr 41, poz. 281; tamże, nr 54, poz. 391; tamże, nr 62, poz. 437; tamże, nr 74, poz. 517; tamże, nr 86, poz. 593; tamże, nr 97, poz. 685; tamże, nr 107, poz. 762; tamże, nr 117, poz. 839; tamże, nr 129, poz. 918. 


\begin{tabular}{l|l|l|l|l|l|l} 
III-V 1925 & 746,20 & 787,20 & 828,20 & 869,20 & 910,20 & 951,20 \\
VI 1925 & 728,00 & 768,00 & 808,00 & 848,00 & 888,00 & 928,00 \\
VII 1925 & 739,20 & 781,20 & 823,20 & 865,20 & 907,20 & 949,20 \\
VIII 1925 & 756,80 & 799,80 & 842,80 & 885,80 & 928,80 & 971,80 \\
IX 1925 & 739,20 & 781,20 & 823,20 & 865,20 & 907,20 & 949,20 \\
X 1925 & 756,80 & 799,80 & 842,80 & 885,80 & 928,80 & 971,80 \\
XI 1925 & 774,40 & 818,40 & 862,40 & 906,40 & 950,40 & 994,40 \\
XII 1925 & 756,80 & 799,80 & 842,80 & 885,80 & 928,80 & 971,80 \\
I-III 1926 & 650,76 & 691,18 & 731,60 & 772,02 & 812,44 & 832,65 \\
IV 1926-I 1934 & 692,30 & 735,30 & 778,30 & 821,30 & 864,30 & 885,80 \\
\hline
\end{tabular}

\section{Uposażenie uzupełniające - uwagi ogólne}

Zasadniczo wszystkie dodatki wchodzące w skład uposażenia uzupełniajacego były wypłacane razem z uposażeniem podstawowym i na analogicznych zasadach. Zatem $\mathrm{w}$ tym miejscu ograniczę się jedynie do zwrócenia uwagi na dodatkowe elementy, związane ze specyfika dodatków.

Ponieważ niektóre składowe uposażenia lub ich wysokość (dodatek ekonomiczny i dodatek mieszkaniowy) zwiąane były z wielkościa posiadanej przez profesora rodziny, należy zapoznać się z kryteriami uwzględniania członków rodziny dla celów obliczenia należnego uposażenia.

Do rodziny profesora zaliczano zasadniczo małżonka oraz dzieci. Uwzględniano jednak wyłącznie tych członków rodziny, którzy znajdowali się na jego utrzymaniu. Jeżeli oboje małżonkowie pozostawali w służbie państwowej, przy naliczaniu uposażenia dla męża nie uwzględniano żony. Chodziło przede wszystkim o unikniecie podwójnego liczenia członków rodziny dla celów uposażeniowych, minimalna zaś dyskryminacja żony była związana z ideologicznym założeniem, że głównie na mężu ciaży obowiązek utrzymywania rodziny. Kobieta zamężna na stanowisku profesora zwyczajnego była zatem traktowana zasadniczo jako samotna, męża i dzieci uwzględniano jej tylko, jeżeli udowodniła, że maż był całkowicie niezdolny do zarobkowania. W razie separacji żonę uwzględniano tylko jeżeli profesor został zobowiązany do jej utrzymywania wyrokiem sądu, co musiał udowodnić.

Dziecko mogło być zarówno ślubne, prawnie uznane, jak i przysposobione. Uwzględniano je zasadniczo do ukończenia 18. roku życia. Jednak jeżeli dziecko uczęszczało do szkoły publicznej, uwzględniano je do 
ukończenia 24. roku życia. Ciężar dowodu spoczywał na zainteresowanym zwiększeniem swego uposażenia. Dowód taki musiał mieć formę dokumentu urzędowego, gdyż tylko taki mógł być uznany za wiążący dla organu naliczającego uposażenie. Jeżeli studia przedłużały się ponad powyższą granicę wieku z powodu służby wojskowej, odbytej na skutek mobilizacji lub uzupełnienia etatu sił zbrojnych do stanu wojennego albo z powodu pełnionej w tym czasie służby ochotniczej, minister wyznań religijnych i oświecenia publicznego mógł, w drodze wyjątku, uwzględnić dzieci mające więcej niż 24 lata do momentu ukończenia nauki w szkole wyższej. Dla zaliczenia do wyższej grupy rodzinnej miarodajny był moment wznowienia studiów. Nie uwzględniano dziecka, które weszło w związek małżeński, utrzymywało się samodzielnie lub posiadało własne zaopatrzenie. Dziecko dotknięte kalectwem, uniemożliwiającym samodzielne utrzymanie, uwzględniano do ukończenia 24. roku życia. Minister wyznań religijnych i oświecenia publicznego mógł zadecydować, w drodze wyjątku, o uwzględnieniu go nawet po przekroczeniu tej granicy wieku. Ponieważ stan zdrowia mogło wiarygodnie określić jedynie świadectwo lekarskie, z całą pewnością musiało ono być przedkładane organowi naliczającemu uposażenie ${ }^{48}$.

\section{Dodatek ekonomiczny}

Od 1 X 1923 r. wprowadzono dodatek ekonomiczny do uposażenia zasadniczego, który w pewnym sensie zastapił dodatek drożyźniany znany z poprzednio obowiązującego systemu mnożnikowego. Dodatku tego nie można zaliczyć do kategorii uposażenia podstawowego, gdyż nie przysługiwał on w ogóle profesorom samotnym, nieposiadającym rodziny. Spośród składowych uposażenia uzupełniającego dodatek ekonomiczny miał bezsprzecznie największe znaczenie. Jego wysokość nie pozostawała $\mathrm{w}$ związu ani $\mathrm{z}$ zaszeregowaniem do określonej grupy i szczebla uposażenia, ani z przysługujacca kwota innych składowych uposażenia. Zasadniczo wszyscy funkcjonariusze państwowi otrzymywali ów dodatek w identycznej wysokości, zależnie od liczebności rodziny. Przy czym przewidywano pięć wariantów w tym zakresie.

Dodatek ekonomiczny przysługiwał na każdego członka rodziny, ale na nie więcej niż pięciu (nie wliczano samego profesora). Posiadanie rodziny większej nie dawało już prawa do kolejnych dodatków. Dodatek ekonomiczny wypłacano co miesiąc, wraz z uposażeniem podstawowym.

${ }^{48}$ Dz. U. 1923, nr 116, poz. 924. 
Jego wielkość wyrażano w punktach i była ona równa dla wszystkich szczebli uposażenia. Pierwotna wartość dodatku ekonomicznego ustalono na 45 pkt. na członka rodziny, czyli łącznie nie więcej niż 225 pkt. Zatem dodatek ekonomiczny dla profesora zwyczajnego utrzymującego 1 członka rodziny miał wartość 45 pkt., dla utrzymującego 2 osoby 90 pkt., dla utrzymującego 3 osoby - 135 pkt., dla utrzymujacego 4 osoby -180 pkt., dla utrzymującego 5 lub więcej osób -225 pkt. W razie gdy na mężu ciążył obowiązek alimentowania żony, suma dodatku ekonomicznego na żonę nie mogła przewyższać sumy alimentów ${ }^{49}$. Wysokość dodatku ekonomicznego w okresie markowym przedstawia tabela 8 .

Tabela 8. Miesięczny dodatek ekonomiczny do płacy zasadniczej profesora zwyczajnego w okresie od 1 X 1923 do 30 VI 1924 r. w mk ${ }^{50}$

\begin{tabular}{l|r|r|r|r|r}
\hline \multirow{2}{*}{ Okres } & \multicolumn{6}{|c}{ Liczba czlonków rodziny } \\
\cline { 2 - 6 } & \multicolumn{1}{|c|}{$\mathbf{1}$} & $\mathbf{2}$ & \multicolumn{1}{c}{$\mathbf{3}$} & \multicolumn{1}{c}{$\mathbf{4}$} & \multicolumn{1}{c}{$\mathbf{5}$} \\
\hline X 1923 & 616500 & 1233000 & 1849500 & 2466000 & 3082500 \\
XI 1923 & 1917900 & 3835800 & 5753700 & 7671600 & 9589500 \\
XII 1923 & 4461525 & 8923050 & 13384575 & 17846100 & 22307625 \\
I 1924 & 7429905 & 14859810 & 22289715 & 29719620 & 37149525 \\
II 1924 & 22907880 & 45815760 & 68723640 & 91631520 & 114539400 \\
III 1924 & 29592405 & 59184810 & 88777215 & 118369620 & 147962025 \\
IV 1924 & 28044000 & 56088000 & 84132000 & 112176000 & 140220000 \\
V-VI 1924 & 29160000 & 58320000 & 87480000 & 116640000 & 145800000 \\
\hline
\end{tabular}

Pierwotna wartość dodatku ekonomicznego na członka rodziny miała ulegać redukcji z mocy prawa równolegle z redukcją dodatku regulacyjnego, o 1 pkt co pół roku, do poziomu 38 pkt. na członka rodziny. W odróżnieniu od dodatków regulacyjnego i naukowego, miał on pozostać trwałą częścią uposażenia, tyle że w zmniejszonej wysokości.

Termin rozpoczęcia redukcji dodatku regulacyjnego został ostatecznie wyznaczony na 1 VII 1925 r., z tym dniem doszło również do pierwszej redukcji dodatku ekonomicznego (do poziomu 44 pkt. na członka rodziny $)^{51}$. Okazała się ona redukcją ostatnią i od tego momentu wysokość dodatku ekonomicznego nie ulegała już zmianie.

${ }^{49}$ Tamże.

${ }^{50}$ Oprac. i obliczenia własne na podstawie: Dz. U. 1923, nr 116, poz. 924; tamże, nr 117, poz. 937; tamże, nr 121, poz. 973; tamże, nr 124, poz. 1002; tamże, nr 131, poz. 1066 ; Dz. U. 1924 , nr 7, poz. 68 ; tamże, nr 17, poz. 174 ; tamże, nr 28, poz. 277; tamże, nr 35, poz. 370; tamże, nr 43, poz. 453.

${ }^{51}$ Dz. U. 1925, nr 62, poz. 438. 
Dodatek ekonomiczny wyliczany był podobnie jak składniki uposażenia podstawowego. Jego miesięczną wartość obliczano, mnożąc liczbę punktów przypisanych temu typowi dodatku w danym miesiącu przez każdorazową mnożna ${ }^{52}$. Przy stałej mnożnej wynoszącej $0,43 \mathrm{zl}$, dawało to kwotę dodatku ekonomicznego wynosząca $18,92 \mathrm{zł}$ miesięcznie na członka rodziny ${ }^{53}$. Tymczasowo, w okresie od 1 I do 31 III 1926 r., kwota dodatku ekonomicznego została zmniejszona o 6\% stanu stałego. Oznaczało to, że w styczniu, lutym i marcu 1926 r. dodatek ekonomiczny do płacy zasadniczej profesora zwyczajnego wynosił 17,78 zł (oczywiście wymagało to zaokraglenia do pełnego grosza) na członka rodziny ${ }^{54}$.

\section{Dodatek osobisty}

Od 1 X 1923 r. minister wyznań religijnych i oświecenia publicznego, w porozumieniu z ministrem skarbu, mógł przyznać określonemu profesorowi zwyczajnemu dodatek osobisty. Mógł być on przyznany tylko w wyjątkowym przypadku, specjaliście w danej dziedzinie nauki, zatem powinno to dotyczyć jednostek wybitnych, którym, aby je pozyskać lub utrzymać na stanowisku profesorskim, należało zaoferować bardziej konkurencyjne warunki zatrudnienia niż instytucje prywatne lub zagraniczne ${ }^{55}$. Dodatek taki miał zatem pełnić rolę nadzwyczajnego bodźca do pozostawania na stanowisku.

Przyznanie dodatku osobistego było fakultatywne i całkowicie zależne od ministra wyznań religijnych i oświecenia publicznego. Jego wysokość nie była ustawowo określona. Co prawda nie wskazano żadnych ustawowych granic jego wysokości, jednak nie należy sięgać wyobraźnią zbyt daleko i to co najmniej z dwóch powodów. Po pierwsze, państwo polskie nie należało do najbogatszych. Po drugie, unikano astronomicznego wyróżniania finansowego kogokolwiek, aby nie „psuć atmosfery” w środowisku naukowym. Tym bardziej że rzadko się zdarza, aby nawet najwybitniejsi uczeni nie wzbudzali jakichś kontrowersji. A szczerze powiedziawszy, to właśnie oni owe kontrowersje najczęściej wywoływali, co było niejako pośrednim wyrazem ich znaczenia w nauce.

W każdym razie od 1 I $1926 \mathrm{r}$. tymczasowo, w okresie od 1 I do 31 III 1926 r., także kwota dodatku osobistego została zmniejszona o 6\% sta-

${ }^{52}$ Dz. U. 1923, nr 116, poz. 924.

${ }^{53}$ Taką bowiem wartość dodatek ekonomiczny przyjmował według stanu na 1 XII $1925 \mathrm{r}$.

${ }^{54}$ Dz. U. 1925, nr 129, poz. 918.

${ }^{55}$ Dz. U. 1923, nr 116, poz. 924. 
nu przysługującego w grudniu 1925 r., co w intencji prawodawcy miało być jednym z czynników wspomagających osiagnięcie równowagi budżetowej przez Skarb Państwa ${ }^{56}$.

\section{Dodatek funkcyjny}

Dodatek funkcyjny przysługiwał profesorowi zwyczajnemu jedynie gdy przepisy państwowe przewidywały takowy dla określonej funkcji w szkole akademickiej. Dodatek funkcyjny, w odniesieniu do stanowisk w szkolnictwie akademickim, określany był w II RP różnymi nazwami. Od 1 VII 1920 do 31 XII 1921 r. przepisy państwowe mówiły o wynagrodzeniu za czynności dodatkowe ${ }^{57}$, od 1 I 1922 r. o dodatku funkcyjnym $^{58}$, od 1 II 1934 r. zaś o dodatku służbowym ${ }^{59}$.

Od 1 X 1923 do 31 XII 1925 r. dodatki funkcyjne wynosiły miesięcznie: dla rektora szkoły akademickiej o co najmniej 4 wydziałach 300 pkt., dla rektora szkoły akademickiej do 3 wydziałów - 250 pkt., dla dziekana i dyrektora studium o własnym statucie - 200 pkt., dla kierownika dużego zakładu naukowego - 150 pkt., dla kierownika małego zakładu naukowego i seminarium - 100 pkt. ${ }^{60}$

Dodatek funkcyjny wyliczany był podobnie jak składniki uposażenia podstawowego. Jego miesięczną wartość obliczano, mnożąc liczbę punktów przypisanych temu typowi dodatku w danym miesiącu przez każdorazową mnożną. Wysokość dodatku funkcyjnego w okresie markowym przedstawia tabela 9 .

Od 1 I 1926 do 31 III 1927 r. dodatki funkcyjne zostały zmniejszone o $50 \%$, przy stałej mnożnej uposażeniowej wynoszącej $0,43 \mathrm{zz}^{61}$. Dodatki funkcyjne wynosiły zatem odtąd miesięcznie: dla rektora szkoły akademickiej o co najmniej 4 wydziałach - 150 pkt., czyli 64,5 zł; dla rektora szkoły akademickiej do 3 wydziałów - 125 pkt., czyli 53,75 zł; dla dziekana i dyrektora studium o własnym statucie - 100 pkt., czyli 43 zł; dla kierownika dużego zakładu naukowego - 75 pkt., czyli

${ }^{56}$ Dz. U. 1925 , nr 129, poz. 918.

${ }^{57}$ Dz. U. 1920, nr 65, poz. 432.

${ }^{58}$ Rozporządzenie Rady Ministrów z dnia 14 VIII 1922 r. o wykonaniu ustawy z dnia 31 III 1922 r. o uposażeniu profesorów i pomocniczych sił naukowych w szkołach akademickich, Dz. U. 1922, nr 74, poz. 669.

${ }^{59}$ Dz. U. 1933, nr 86, poz. 663.

${ }^{60}$ Dz. U. 1923, nr 116, poz. 924.

${ }^{61}$ Taka bowiem wartość mnożna uposażeniowa przyjmowała według stanu na 1 XII 1925 r. 
32,25 zł; dla kierownika małego zakładu naukowego i seminarium 50 pkt., czyli $21,5 \mathrm{zł}^{62}$.

Tabela 9. Miesięczny dodatek funkcyjny do płacy zasadniczej profesora zwyczajnego w okresie od 1 X 1923 do 30 VI 1924 r. w mk ${ }^{63}$.

\begin{tabular}{l|r|r|r|r|r}
\hline \multirow{2}{*}{ Okres } & \multicolumn{5}{|c}{ Funkcja } \\
\cline { 2 - 6 } & Rektor (D) & Rektor (M) & \multicolumn{1}{c}{ Dziekan } & Kierownik (D) & $\begin{array}{c}\text { Kierownik } \\
\text { (M) }\end{array}$ \\
\hline X 1923 & 4110000 & 3425000 & 2740000 & 2055000 & 1370000 \\
XI 1923 & 12786000 & 10655000 & 8524000 & 6393000 & 4262000 \\
XII 1923 & 29743500 & 24786250 & 19829000 & 14871750 & 9914500 \\
I 1924 & 49532700 & 41277250 & 33021800 & 24766350 & 16510900 \\
II 1924 & 152719200 & 127266000 & 101812800 & 76359600 & 50906400 \\
III 1924 & 197282700 & 164402250 & 131521800 & 98641350 & 65760900 \\
IV 1924 & 186960000 & 155800000 & 124640000 & 93480000 & 62320000 \\
V-VI 1924 & 194400000 & 162000000 & 129600000 & 97200000 & 64800000 \\
\hline
\end{tabular}

Od 1 IV 1927 r. dodatki funkcyjne zostały przywrócone do pierwotnego poziomu i wynosiły: dla rektora szkoły akademickiej o co najmniej 4 wydziałach - 300 pkt. miesięcznie, czyli 129 zł; dla rektora szkoły akademickiej do 3 wydziałów - 250 pkt. miesięcznie, czyli 107,5 zł; dla dziekana i dyrektora studium o własnym statucie - 200 pkt. miesięcznie, czyli 86 zł; dla kierownika dużego zakładu naukowego - 150 pkt. miesięcznie, czyli 64,5 zł; dla kierownika małego zakładu naukowego i seminarium - 100 pkt. miesięcznie, czyli $43 z^{6}{ }^{64}$.

Tabela 10 przedstawia wysokość rzeczywistego miesięcznego dodatku funkcyjnego w okresie od 1 V 1924 do 31 VIII 1933 r. w zł.

\footnotetext{
${ }^{62}$ Dz. U. 1925 , nr 129, poz. 918.

${ }^{63}$ Rektor (D) - rektor szkoły akademickiej o co najmniej 4 wydziałach, rektor (M) - rektor szkoły akademickiej do 3 wydziałów, dziekan - także dyrektor studium o własnym statucie, kierownik (D) - kierownik dużego zakładu naukowego, kierownik (M) - kierownik małego zakładu naukowego. Oprac. i obliczenia własne na podstawie: Dz. U. 1923, nr 116, poz. 924; tamże, nr 117, poz. 937; tamże, nr 121, poz. 973; tamże, nr 124, poz. 1002; tamże, nr 131, poz. 1066; Dz. U. 1924, nr 7, poz. 68; tamże, nr 17 , poz. 174; tamże, nr 28, poz. 277; tamże, nr 35, poz. 370; tamże, nr 43, poz. 453.

${ }^{64}$ Ustawa z dnia 1 III $1927 \mathrm{r}$. zmieniajacca niektóre postanowienia ustawy z dnia 9 X 1923 r. o środkach zapewnienia równowagi budżetowej (Dz. U. R. P. z 1925, nr 129, poz. 918), Dz. U. 1927, nr 27, poz. 207.
} 
Tabela 10. Miesięczny dodatek funkcyjny do płacy zasadniczej profesora zwyczajnego w okresie od 1 V 1924 do 31 VIII 1933 r. w zł ${ }^{65}$

\begin{tabular}{l|c|c|c|c|c}
\hline \multirow{2}{*}{\multicolumn{1}{c|}{ Okres }} & \multicolumn{3}{|c}{ Funkcja } \\
\cline { 2 - 5 } & Rektor (D) & Rektor (M) & Dziekan & $\begin{array}{c}\text { Kierownik } \\
\text { (D) }\end{array}$ & $\begin{array}{c}\text { Kierownik } \\
\text { (M) }\end{array}$ \\
\hline V-VI 1924 & 108,00 & 90,00 & 72,00 & 54,00 & 36,00 \\
VII-IX 1924 & 105,00 & 87,50 & 70,00 & 52,50 & 35,00 \\
X 1924 & 114,00 & 95,00 & 76,00 & 57,00 & 38,00 \\
XI-XII 1924 & 123,00 & 102,50 & 82,00 & 61,50 & 41,00 \\
I-II 1925 & 126,00 & 105,00 & 84,00 & 63,00 & 42,00 \\
III-V 1925 & 123,00 & 102,50 & 82,00 & 61,50 & 41,00 \\
VI 1925 & 120,00 & 100,00 & 80,00 & 60,00 & 40,00 \\
VII 1925 & 126,00 & 105,00 & 84,00 & 63,00 & 42,00 \\
VIII 1925 & 129,00 & 107,50 & 86,00 & 64,50 & 43,00 \\
IX 1925 & 126,00 & 105,00 & 84,00 & 63,00 & 42,00 \\
X 1925 & 129,00 & 107,50 & 86,00 & 64,50 & 43,00 \\
XI 1925 & 132,00 & 110,00 & 88,00 & 66,00 & 44,00 \\
XII 1925 & 129,00 & 107,50 & 86,00 & 64,50 & 43,00 \\
I 1926-III 1927 & 64,50 & 53,75 & 43,00 & 32,25 & 21,50 \\
IV 1927-VIII 1933 & 129,00 & 107,50 & 86,00 & 64,50 & 43,00 \\
\hline
\end{tabular}

Od 1 IX 1933 r. radykalnie zmieniono sposób obliczania dodatku funkcyjnego. Zamiast określać jego wysokość w punktach, przypisano każdej funkcji określoną kwotę wyrażona w $\mathrm{z}^{66}$. Dodatek funkcyjny wynosił odtąd miesięcznie dla: rektora uniwersytetu i politechniki 500 zł, rektora Szkoły Głównej Gospodarstwa Wiejskiego w Warszawie i Akademii Górniczej w Krakowie - 400 zł, dla rektora Akademii Me-

${ }^{65}$ Rektor (D) - rektor szkoły akademickiej o co najmniej 4 wydziałach, rektor (M) - rektor szkoły akademickiej do 3 wydziałów, dziekan - także dyrektor studium o własnym statucie, kierownik (D) - kierownik dużego zakładu naukowego, kierownik (M) - kierownik małego zakładu naukowego. Oprac. i obliczenia własne na podstawie: Dz. U. 1923, nr 116, poz. 924; tamże, nr 117, poz. 937; tamże, nr 121, poz. 973; tamże, nr 124, poz. 1002; tamże, nr 131, poz. 1066; Dz. U. 1924 , nr 7 , poz. 68 ; tamże, nr 17 , poz. 174; tamże, nr 28, poz. 277; tamże, nr 35, poz. 370; tamże, nr 43, poz. 453; tamże, nr 52, poz. 527; tamże, nr 64, poz. 632; tamże, nr 73, poz. 726; tamże, nr 82 , poz. 784; tamże, nr 93, poz. 867; tamże, nr 101, poz. 929; tamże, nr 112, poz. 997; Dz. U. 1925, nr 7, poz. 52; tamże, nr 18, poz. 132; tamże, nr 28, poz. 198; tamże, nr 41, poz. 281; tamże, nr 54, poz. 391; tamże, nr 62, poz. 437; tamże, nr 74, poz. 517; tamże, nr 86, poz. 593; tamże, nr 97, poz. 685; tamże, nr 107, poz. 762; tamże, nr 117, poz. 839; tamże, nr 129, poz. 918; Dz. U. 1927, nr 27, poz. 207.

${ }^{66}$ Dz. U. 1933, nr 29, poz. 247. 
dycyny Weterynaryjnej we Lwowie, Akademii Sztuk Pięknych w Krakowie i Akademii Stomatologicznej w Warszawie - 300 zl, dla prorektora uniwersytetu i politechniki - 300 zł, dla prorektora Szkoły Głównej Gospodarstwa Wiejskiego w Warszawie i Akademii Górniczej w Krakowie - 250 zł, dla prorektora Akademii Medycyny Weterynaryjnej we Lwowie, Akademii Sztuk Pięknych w Krakowie i Akademii Stomatologicznej w Warszawie - 200 zł, dla dziekana uniwersytetu i politechniki - 250 zł, dla dziekana Szkoły Głównej Gospodarstwa Wiejskiego w Warszawie i Akademii Górniczej w Krakowie - 200 zł, kierownicy oddziałów i studiów mających własne statuty -200 zł. Przy czym przysługiwał on jedynie za okres faktycznego pełnienia przez nich obowiązów związanych z danym urzędem. Warto zwrócić uwagę, że wynagrodzenie stałe miał otrzymywać również prorektor, którzy poprzednio miał do niego prawo tylko w przypadku pełnienia obowiązków rektorskich ${ }^{67}$.

\section{Dodatek mieszkaniowy}

Inny charakter miał dodatek mieszkaniowy. Przysługiwał on jedynie czasowo, w okresie od 1 VI 1924 do 31 XII 1925 r. Jego wysokość uzależniona była od miejsca zamieszkania i wielkości rodziny. Dodatek na mieszkanie wypłacano profesorowi zwyczajnemu razem z płaca zasadniczą. W razie zmiany miejsca służbowego, pociagającej za sobą zmianę wysokości uposażenia, przysługiwało profesorowi zwyczajnemu prawo do dodatku, odpowiadającego nowemu miejscu służbowemu, od 1. dnia miesiąca następującego po zwolnieniu go od poprzednich obowiązków służbowych ${ }^{68}$.

W czerwcu 1924 r. dla profesora zwyczajnego utrzymującego rodzinę dodatek na mieszkanie był równy 15\% stawki komornego, która wynosiła dla: Warszawy - 200 zł, Lwowa i Krakowa - 189 zł, Wilna - 136 zł, Poznania - 56 zł. Dla profesora samotnego dodatek na mieszkanie w czerwcu 1924 r. wynosił 10\% stawki komornego, która wynosiła dla: Warszawy - 80 zł, Lwowa i Krakowa - 74 zł, Wilna - 55 zł, Poznania - 33 zł. Oznaczało to, że dodatek mieszkaniowy dla utrzymującego rodzinę wynosił miesięcznie w: Warszawie - $30 \mathrm{zł}$, Lwowie i Krakowie 28,35 zł, Wilnie - 20,40 zł, Poznaniu - 8,40 zł. Dodatek mieszkaniowy

${ }^{67}$ Rozporządzenie Ministra Wyznań Religijnych i Oświecenia Publicznego z dnia 31 VIII 1933 r. wydane w porozumieniu z Ministrem Skarbu, ustalające wysokość dodatkowych wynagrodzeń rektora, prorektorów, dziekanów i kierowników oddziałów i studiów w państwowych szkołach akademickich, Dz. U. 1933, nr 73, poz. 534.

${ }^{68}$ Dz. U. 1923, nr 116, poz. 924. 
dla samotnego wynosił miesięcznie w: Warszawie -8 zł, Lwowie i Krakowie - 7,40 zł, Wilnie - 5,50 zł, Poznaniu - 3,30 zł.

Począwszy od 1 VII 1924 r., wysokość dodatku na mieszkanie wzrastała co kwartał. W III kwartale o 4\% stawki komornego, czyli wynosił dla: utrzymującego rodzinę - 19\%, samotnego - 14\%. W IV kwartale 1924 r. o dalsze 4\% stawki komornego, czyli wynosił dla: utrzymującego rodzinę $-23 \%$, samotnego $-18 \%{ }^{69}$. W I kwartale 1925 r. rósł o kolejne $6 \%$ stawki komornego, czyli wynosił dla: utrzymującego rodzinę - 29\%, samotnego - $24 \%$. W II kwartale 1925 r. o dalsze $6 \%$ stawki komornego, czyli wynosił dla: utrzymującego rodzinę - 35\%, samotnego - $30 \%$. W III kwartale $1925 \mathrm{r}$. jeszcze o 6\% stawki komornego, czyli wynosił dla: utrzymujacego rodzinę - 41\%, samotnego - 36\%. W IV kwartale 1925 r. o kolejne $6 \%$ stawki komornego, czyli wynosił dla: utrzymujacego rodzinę $-47 \%$, samotnego $-42 \%{ }^{70}$.

Zapewne w związku z problemami budżetu państwa postanowiono zrezygnować z dalszego utrzymywania dodatku mieszkaniowego. Od 1 I 1926 r. przestał on być wypłacany. Miesięczną wysokość dodatku mieszkaniowego w całym okresie jego przysługiwania przedstawia tabela 11.

Tabela 11. Miesięczny dodatek mieszkaniowy przysługujący profesorowi zwyczajnemu w okresie od 1 VI 1924 do 31 XII 1925 r. w zł ${ }^{71}$

\begin{tabular}{l|l|r|r|r|r}
\hline \multicolumn{1}{c|}{ Okres } & \multicolumn{1}{c|}{$\begin{array}{c}\text { Status } \\
\text { rodzinny }\end{array}$} & Warszawa & $\begin{array}{c}\text { Kraków } \\
\text { i Lwów }\end{array}$ & Wilno & Poznań \\
\hline VI 1924 & samotny & 8,00 & 7,40 & 5,50 & 3,30 \\
& z rodzina & 30,00 & 28,35 & 20,40 & 8,40 \\
VII-IX 1924 & samotny & 11,20 & 10,36 & 7,70 & 4,62 \\
& z rodzina & 38,00 & 35,91 & 25,84 & 10,64 \\
X-XII 1924 & samotny & 14,40 & 13,32 & 9,90 & 5,94 \\
& z rodzina & 46,00 & 43,47 & 31,28 & 12,88 \\
I-III 1925 & samotny & 19,20 & 17,76 & 13,20 & 7,92 \\
& z rodzina & 58,00 & 54,81 & 39,44 & 16,24 \\
IV-VI 1925 & samotny & 24,00 & 22,20 & 16,50 & 9,90 \\
& z rodzina & 70,00 & 66,15 & 47,60 & 19,60 \\
VII-IX 1925 & samotny & 28,80 & 26,64 & 19,80 & 11,88 \\
& z rodzina & 82,00 & 77,49 & 55,76 & 22,96 \\
X-XII 1925 & samotny & 33,60 & 31,08 & 23,10 & 13,86 \\
& z rodziną & 94,00 & 88,83 & 63,92 & 26,32
\end{tabular}

${ }^{69}$ Rozporządzenie Rady Ministrów z dnia 30 VII 1924 r. w sprawie dodatku na mieszkanie, Dz. U. 1924, nr 69, poz. 673.

${ }^{70}$ Wzrost ten następował w tym samym stosunku, w jakim wzrastało komorne w myśl art. 6 ust. 3 Ustawy z dnia 11 IV 1924 r. o ochronie lokatorów, Dz. U. 1924, nr 39, poz. 406; tamże, nr 69, poz. 673.

${ }^{71}$ Oprac. własne na podstawie: Dz. U. 1924, nr 69, poz. 673; tamże, nr 39, poz. 406. 


\section{Zakończenie}

System punktowy, który był przedmiotem niniejszych rozważań, sprawdził się całkiem dobrze w warunkach dużej niestabilności wartości pieniądza, wsparł reformę walutową i pozwolił na odzyskanie zaufania funkcjonariuszy państwowych do państwa. Choć był dość złożony i rozbudowany, to nie można mu odmówić pewnej logiki. Gdy inflacja przestała jednak stanowić realną groźbę, a wielki kryzys gospodarczy wywołał wręcz napięcia deflacyjne, rząd sanacyjny postanowił odejść od dotychczasowych rozwiazań płacowych i wprowadzić znacznie prostszy system kwotowy, w którym nie było już konieczności dokonywania przeliczeń, a przez to znacznie upraszczano działalność kwestury i innych organów uprawnionych do naliczania uposażeń.

Jarosław Jastrzębski

Salary of the Ordinary Professor in Polish State Schools of Higher Learning from 1 October 1923 to 31 January 1934

(Summary)

A presentation of the principles of the functioning of the remuneration system concerning ordinary professors in Polish state academic institutions in 1923-1934 and changing salaries during this period. The discussed questions are considered against the background of key moments in the economic history of the Second Republic and state finances: hyperinflation (1923-1924), the Władysław Grabski currency reform (1924), and the great economic crisis (1929-1934).

The article, based on sources, analyses state legal acts from 1918-1934. The introduction outlines stages in the transformation of legislation pertaining to remuneration in schools of higher learning and the place of the discussed rating system, preceded by the multiplier system from 1920-1923 and succeeded by the quota system from 1934-1939. The author goes on to present the essence of the rating system binding at the time while distinguishing components of remuneration: fundamental (basic wages, regulation and scientific bonuses) and supplementary (economic, personal, function and housing bonuses). 